\title{
Pelatihan Manajemen Data Kependudukan dengan Ms. Excel di Desa Gedangan Kecamatan Sidayu Gresik
}

(Population Data Management Training with Ms. Excel in Gedangan Village, Sidayu Gresik District)

\author{
Fenny Fitriani $^{1 *}$, Gangga Anuraga ${ }^{2}$, Artanti Indrasetianingsih ${ }^{3}$ \\ ${ }^{1,2,3}$ Prodi Statistika, Fakultas Sains dan Teknologi, Universitas PGRI Adi Buana Surabaya, Jl. Dukuh \\ Menanggal XII, Surabaya, Jawa Timur, 60234
}

\section{ARTICLE INFO}

Article history

Received : 31 October 2020

Revised : 17 November 2020

Accepted : 24 November 2020

DOI :

http://dx.doi.org/10.33366/jast.v4i2.2021

Keywords

population data;

data management;

Ms. Excel

*e-mail corresponding author :

fenny_f@unipasby.ac.id

\section{c) (1) (2)}

This is an open access article under the Creative Commons Attribution-ShareAlike 4.0 International License. Any further distribution of this work must maintain attribution to the author(s) and the title of the work, journal citation and DOI. CC-BY-SA

\section{ABSTRACT}

Making a voter list is an initial process to support the implementation of regional head elections. Making this voter list was carried out by village officials using population data stored in Ms. Excel. Until now, this process was done manually by sorting age data using the Excel sort function. By carrying out this process, village officials still have to carry out a separate sorting of population data less than 17 years old who have been married. Apart from these data, the data that must be separated by village officials is data on residents over 17 years of age who have died. With these processes, village officials need more time to be able to create voter lists. One of the village officials who carry out the process is the village apparatus in Gedangan Village, Sidayu, Gresik. For solving this problem, training was conducted for ten Gedangan village officials in data management using Ms. Excel. The training materials provided were consolidating the use of sort and filter data, using forms in filling in data and using pivot tables. The method used in this training is to use interactive discussion. The training was held at the village hall in Gedangan Village, Sidayu, Gresik. With this training, village officials could more easily determine the list of voters who met the requirements.

\section{PENDAHULUAN}

Negara Indonesia merupakan negara demokrasi yang memberikan kebebasan kepada warga negaranya untuk dapat ikut berpartisipasi secara langsung dalam proses pemilihan kepemimpinan. Salah satu kepemimpinan yang melibatkan masyarakat umum dalam proses pemilihannya adalah pemilihan seorang kepala daerah. Proses pemilihan kepala daerah dilakukan secara rutin setiap lima tahun sekali. Dalam proses pemilihan ini, masyarakat yang dapat berpartisipasi dalam pelaksanaan pemilihan seorang kepala daerah adalah masyarakat yang telah terdaftar sebagai pemilih dengan memenuhi beberapa persyaratan yang ditentukan. 
Persyarataan yang menjadikan seseorang menjadi pemilih antara lain : 1) merupakan warga negara Indonesia yang telah berusia 17 (tujuh belas) tahun atau sudah/pernah kawin; 2) tidak sedang mengalami gangguan kejiwaan; dan 3) hak pilih yang dimiliki tidak sedang dicabut berdasarkan putusan pengadilan yang telah mempunyai kekuatan hukum tetap (1). Setiap data persyaratan dari seorang pemilih ini harus terekap pada database desa.

Dalam pelaksanaannya, database dari data masyarakat yang dilakukan di pemerintah desa lebih banyak dilakukan dengan menggunakan Ms Excel. Akan tetapi, pengolahan data yang dilakukan masih sangat manual. Hal tersebut dibuktikan dari pengamatan awal yang dilakukan oleh tim pelatihan pada perangkat desa Gedangan di Kabupaten Gresik. Temuan yang didapatkan yaitu pada kegiatan perangkat desa yang sedang melakukan penyortiran data yang digunakan dalam penentuan masyarakat yang telah memenuhi syarat menjadi seorang pemilih. Penyortiran hanya dilakukan dengan menggunakan cara pengurutan data umur lalu baru menelusuri satu persatu data masyarakat di bawah 17 tahun yang telah berstatus sudah/pernah kawin.

Dengan pelaksanaan proses tersebut, maka penentuan pemilih yang layak dalam pemilihan memakan waktu yang relatif lama. Ketidakefektifan tersebut mengakibatkan kurang maksimalnya waktu yang digunakan. Untuk menanggulangi hal tersebut, maka perlu dilakukan suatu pelatihan yang diberikan kepada perangkat desa dalam melakukan pengolahan data yang ada di Ms Excel.
Pelaksanaan pelatihan dengan menggunakan Ms Excel telah banyak dilakukan. Masdelima Azizah Sormin dan tim memberikan pelatihan pemanfaatan perangkat lunak termasuk Ms Excel dengan peserta pelatihan adalah kepala desa se-Kecamatan Batang Angkola (2). Siti Julaeha dan tim memberikan sosialisasi pengoperasian Ms Excel dengan peserta pelatihan karang taruna di kecamatan Jatisampurna (3). Edy Wibowo memberikan pelatihan Ms Excel dan Ms Power Point dengan peserta pelatihan perangkat desa di Kecamatan Jumantono Kabupaten Karanganyar (4). Asih Niati dan tim memberikan pelatihan pengembangan kemampuan penggunaan Ms Excel dengan peserta perangkat desa Mragen (5). Pelatihan yang serupa juga dilakukan oleh Rizaldi, dimana Rizaldi memberikan pelatihan pengolahan data dengan Ms Excel dengan peserta pelatihan yaitu perangkat desa Pinanggripan Kecamatan Air Batu Kabupaten Asahan (6). Heny I. Pratiwi memberikan pelatihan penggunaan Microsoft Office untuk karyawan dan ibu-ibu PKK di Kelurahan Sawah Baru Tanggerang Selatan (7).

Dari pelatihan-pelatihan yang telah dilakukan di atas, didapatkan bahwa peserta pelatihan mendapatkan pemahaman lebih mengenai beberapa fungsi pada Ms Excel yang masih jarang digunakan. Salah satu fungsi yang diberikan dalam pelatihan adalah penggunaan pivot table yang ada pada Ms Excel. Dari hasil pada pelatihan dan pengamatan yang dilakukan, penggunaan pivot table masih jarang digunakan disebabkan karena peserta pelatihan atau perangkat desa mengalami kesulitan 
dalam memahami cara menggunakan pivot table.

Kurangnya pemahaman terhadap pivot table tersebut sangat disayangkan. Hal tersebut disebabkan dengan penggunaan pivot table, maka kita dapat dengan mudah untuk mengolah data jutaan baris dan mengubah data tersebut kedalam bentuk laporan data tabel yang lebih ringkas (8). Selain itu, sesuai dengan penelitian yang dilakukan oleh Ragland dan Ramachandran didapatkan bahwa fungsi pivot table merupakan fungsi yang harus dapat dikuasai oleh akuntan publik maupun seseorang yang bertanggung jawab dalam pengolahan data (9).

Dari hal tersebut, maka perangkat desa perlu untuk dapat menguasai fungsi pivot table. Dengan penguasaan tersebut, maka seorang perangkat desa dapat meningkatkan salah satu kemampuan yang harus dimilikinya yaitu kemampuan manajemen (10). Dengan adanya peningkatan kemampuan manajemen tersebut, maka pengolahan data dalam penentuan pemilih akan menjadi lebih mudah. Sehingga dari penjabaran tersebut di atas, maka tim dosen dari Prodi Statistika Universitas PGRI Adi Buana melakukan kegiatan pelatihan dalam manajemen data kepada perangkat Desa Gedangan di Kabupaten Gresik.

\section{METODE KEGIATAN}

Pelatihan yang diberikan oleh tim dosen dari Prodi Statistika Universitas PGRI Adi Buana dilakukan dengan sasaran peserta adalah perangkat desa dari Desa Gedangan Kecamatan Sidayu Kabupaten Gresik. Jumlah peserta yang mengikuti pelatihan sebanyak 10 orang. Kegiatan pelatihan ini bertempat di balai desa pada Desa Gedangan Kecamatan Sidayu Kabupaten Gresik. Materi yang diberikan pada saat pelatihan adalah manajemen data kependudukan dengan menggunaan Ms Excel. Materi manajemen data yang dimaksud meliputi penggunaan sort data, penggunaan filter data, pemakaian form untuk pengisian data, dan penggunaan pivot table.

Dalam pelaksanaannya, pelatihan yang diberikan dilaksanakan secara tatap muka dengan menggunakan model diskusi interaktif. Pemilihan model diskusi interaktif ini dimaksudkan untuk memancing peserta agar menjadi aktif dan tidak malu dalam menyampaikan permasalahan yang dihadapi. Untuk membantu kelancaran diskusi interaktif ini, maka selama kegiatan pelatihan dilaksanakan tim dosen dibantu oleh mahasiswa untuk memberikan fasilitas pelayanan kepada peserta. Dengan adanya bantuan dari mahasiswa ini berakibat apabila peserta mengalami kesulitan bisa mendapatkan bantuan lebih cepat.

Untuk mengetahui keberhasilan pelatihan yang diberikan, maka sebelum dan sesudah pelaksanaan kegiatan pelatihan peserta diberikan soal pre-test dan soal post-test. Soal pre-test dan soal post-test yang diberikan berupa soal uraian singkat mengenai penggunaan sort data, penggunaan filter data, pemakaian form untuk pengisian data, dan penggunaan pivot table. Jumlah soal yang diberikan sebanyak 20 soal.

\section{KARYA UTAMA}

Kegiatan pelatihan manajemen data kependudukan di Desa Gedangan ini dilaksanakan dalam beberapa tahapan, yaitu tahap persiapan, tahap pelaksanaan, 
dan tahap evaluasi. Berikut merupakan penjabaran dari setiap tahapan yang dilakukan:

\subsection{Tahap Persiapan}

Pada tahap persiapan pelaksanaan pelatihan, tim dosen Prodi Statistika UNIPA Surabaya melakukan kegiatan koordinasi baik secara internal maupun koordinasi secara eksternal. Kegiatan koordinasi internal dilaksanakan dalam penentuan beberapa tema yang ditawarkan kepada pihak sasaran pelatihan. Hasil dari koordinasi internal tersebut yang dibawa sebagai bahan dalam kegiatan koordinasi eksternal dengan perangkat Desa Gedangan.

Hasil koordinasi eksternal yang dilakukan dengan perangkat Desa Gedangan antara lain 1) tema yang digunakan pada pelaksanaan pelatihan adalah mengenai manajemen data dengan Ms Excel; 2) pemberian izin pelaksanaan pelatihan; 3) penentuan tempat dan waktu dilaksanakannya pelatihan; 4) sasaran peserta yang diundang; dan 5) gambaran umum mengenai pengetahuan calon peserta pelatihan dalam pengolahan data dengan mengggunakan Ms Excel.

Dari hasil koordinasi tersebut, maka tim dosen dengan mendapat bantuan dari pihak desa untuk menyebarkan soal pretest kepada calon peserta pelatihan. Dari hasil soal pre-test yang telah diisi oleh calon peserta pelatihan, didapatkan bahwa pengetahuan calon peserta pelatihan terhadap penggunaan sort data dan penggunaan filter data masih sangat dasar. Selain itu, dari hasil pre-test juga didapatkan bahwa calon peserta pelatihan tidak pernah menggunakanan fasilitas form untuk pengisian data dan pivot table dalam pengolahan datanya.

Dari 20 pertanyaan yang diberikan kepada peserta pada soal pre-test, soalsoal tersebut dapat dikelompokkan kedalam 10 point utama yaitu 3 point mengenai penggunaan sort, 3 point mengenai penggunaan filter, 2 point mengenai penggunaan form, dan 2 point mengenai penggunaan pivot table. Berikut merupakan hasil dari pre-test dari peserta:

Tabel 1 Hasil pre-test untuk setiap garis besar pertanyaan

\begin{tabular}{|c|c|c|}
\hline No & Garis Besar Pertanyaan & $\begin{array}{l}\text { Prosentase } \\
\text { Kebenaran }\end{array}$ \\
\hline 1 & $\begin{array}{l}\text { Penyelesain kasus dengan } \\
\text { menggunakan sort data jika } \\
\text { terdapat satu kriteria pengurutan }\end{array}$ & $90 \%$ \\
\hline 2 & $\begin{array}{l}\text { Penyelesain kasus dengan } \\
\text { menggunakan sort data jika } \\
\text { terdapat dua kriteria pengurutan }\end{array}$ & $65 \%$ \\
\hline 3 & $\begin{array}{l}\text { Penyelesain kasus dengan } \\
\text { menggunakan sort data jika } \\
\text { terdapat tiga kriteria pengurutan }\end{array}$ & $30 \%$ \\
\hline 4 & $\begin{array}{l}\text { Penyelesain kasus dengan } \\
\text { menggunakan filter data jika } \\
\text { terdapat satu kriteria penyeleksian } \\
\text { data }\end{array}$ & $80 \%$ \\
\hline 5 & $\begin{array}{l}\text { Penyelesain kasus dengan } \\
\text { menggunakan filter data jika } \\
\text { terdapat dua kriteria penyeleksian } \\
\text { data }\end{array}$ & $45 \%$ \\
\hline 6 & $\begin{array}{l}\text { Penyelesain kasus dengan } \\
\text { menggunakan filter data jika } \\
\text { menggunakan logika OR atau } \\
\text { logika AND }\end{array}$ & $0 \%$ \\
\hline 7 & $\begin{array}{l}\text { Penyelesaian kasus untuk } \\
\text { mengubah suatu data pada } \\
\text { database Ms Excel yang telah } \\
\text { dimiliki dengan pemanfaatan fitur } \\
\text { di Ms Excel }\end{array}$ & $0 \%$ \\
\hline 8 & $\begin{array}{l}\text { Penyelesaian kasus jika terdapat } \\
\text { data double pada database Ms } \\
\text { Excel yang telah dimiliki }\end{array}$ & $0 \%$ \\
\hline 9 & $\begin{array}{l}\text { Penyelesaian kasus untuk } \\
\text { menjumlahkan atau operasi } \\
\text { numerik lainnya pada data } \\
\text { numerik dari data yang } \\
\text { dibutuhkan dengan dua atau lebih } \\
\text { kriteria dasar yang diberikan }\end{array}$ & $0 \%$ \\
\hline 10 & $\begin{array}{l}\text { Penyelesaian kasus untuk } \\
\text { membuat penyajian data dengan } \\
\text { beberapa tampilan yang berbeda } \\
\text { dari sumber data yang sama } \\
\text { dengan menggunakan fitur di Ms } \\
\text { Excel }\end{array}$ & $0 \%$ \\
\hline
\end{tabular}


Dari hasil tersebut, maka tim dosen melakukan koordinasi internal dengan agenda penyusunan dan simulasi materi yang diberikan kepada peserta pelatihan.

\subsection{Tahap Pelaksanaan}

Kegiatan pelatihan yang diberikan tim dosen Prodi Statistika UNIPA Surabaya dilaksanakan pada tanggal 27 Februari 2020 yang dimulai dari pukul 08.00 sampai dengan 13.00 WIB. Kegiatan pelatihan tersebut bertempat di balai desa yang ada di Desa Gedangan Kecamatan Sidayu Kabupaten Gresik. Jumlah peserta pelatihan sebanyak 10 orang perangkat desa.

Kegiatan pelatihan ini dibuka oleh ketua kegiatan pelatihan yang disertai dengan pemberian gambaran umum mengenai materi apa saja yang disampaikan pada kegiatan pelatihan. Acara kemudian dilanjutkan dengan sambutan pengarahan dari Kepala Desa Gedangan kepada peserta pelatihan (sesuai dengan Gambar 1).

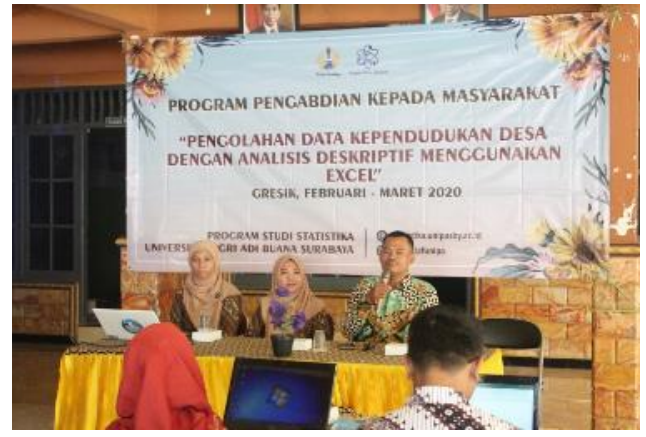

Gambar 1. Pengarahan oleh Kepala Desa Gedangan

Setelah pembukaan dan pengarahan, acara pelatihan dilanjutkan dengan penyampaian materi. Penyampaian materi dilakukan dengan cara diskusi interaktif. Diskusi interaktif yang dimaksud disini adalah dengan memberikan penyampaian materi dengan mengambil permasalahan penentuan data pemilih berdasarkan dengan database data yang telah dimiliki oleh pihak desa. Berdasarkan informasi dari pihak perangkat desa, database yang dimiliki oleh pihak desa disimpan dalam bentuk file Ms Excel.



Gambar 2. Modul pelatihan yang diberikan kepada peserta 
Selain penyampaian materi dengan diskusi interaktif, materi diberikan kepada peserta dalam bentuk modul pelatihan. Modul tersebut dapat dijadikan sebagai dasar peserta untuk mempelajari mengenai manajemen data dengan Ms Excel.



Gambar 3. Penyampaian materi pelatihan

Materi yang disampaikan pada pelaksanaan pelatihan ini antara lain penggunaan sort data, penggunaan filter data, pemakaian form untuk pengisian data, dan penggunaan pivot table. Dalam pelaksanaannya, penyampaian materi mengenai sort data dan filter data disampaian secara singkat. Hal ini didasarkan kepada pengetahuan peserta dalam penggunaan sort dan filter pada data. Penyampaian ini hanya ditekankan pada fungsi tambahan dari sort dan filter data yang belum diketahui oleh peserta.



Gambar 4. Tim Dosen memberikan penjelasan kepada peserta yang mengalami kesulitan
Dalam penyampaian metari mengenai penggunaan form dalam pengisian data, peserta diberi penjelasan mengenai pengertian dasar dari data form pada Ms Excel, bagaimana cara untuk mengaktifkan data form pada Ms Excel, serta cara penggunaan data form pada Ms Excel. Penyampaian materi penggunaan data form pada Ms Excel ini ditujukan untuk memberikan kemudahan kepada peserta dalam mengubah isi data tanpa harus mencari satu-satu header data dari setiap data yang dimiliki.

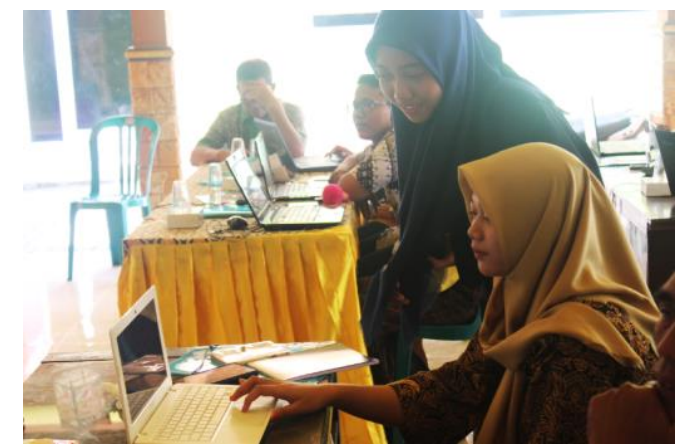

Gambar 5. Mahasiswa memberikan penjelasan kepada peserta yang mengalami kesulitan

Dalam penyampaian materi menganai penggunaan pivot table, peserta mendapatkan penjelasan mengenai pengertian dasar dan manfaat dari pivot table, penjelasan mengenai persiapan dasar yang harus dilakukan pada penggunaan pivot table, cara membuat pivot table, dan cara untuk mengupdate pivot table yang telah dibentuk.

Selain dengan penyampaian materi oleh tim dosen, peserta juga diminta untuk mempraktekkan langsung materi yang didapatkan pada data pelatihan yang diberikan. Dengan adanya praktek secara langsung ini, peserta bisa mendapatkan pengalaman langsung dalam melakukan manajemen data. 


\subsection{Tahap Evaluasi}

Tahapan evaluasi dilaksanakan setelah kegiatan pelatihan dilaksanakan. Sebelum kegiatan pelatihan ditutup, para peserta pelatihan diminta untuk mengisi soal post-test. Dari hasil post-test yang diberikan, didapatkan bahwa pelaksanaan pelatihan mampu untuk meningkatkan pemahaman dari peserta pelatihan dalam penggunaan sort data, penggunaan filter data, pemakaian form untuk pengisian data, dan penggunaan pivot table. Secara garis besar, hasil dari post-test tersebut dapat dilihat pada tabel berikut:

Tabel 2 Hasil post-test untuk setiap garis besar pertanyaan

\begin{tabular}{|c|c|c|}
\hline No & Garis Besar Pertanyaan & $\begin{array}{l}\text { Prosentase } \\
\text { Kebenaran }\end{array}$ \\
\hline 1 & $\begin{array}{l}\text { Penyelesain kasus dengan } \\
\text { menggunakan sort data jika } \\
\text { terdapat satu kriteria pengurutan }\end{array}$ & $100 \%$ \\
\hline 2 & $\begin{array}{l}\text { Penyelesain kasus dengan } \\
\text { menggunakan sort data jika } \\
\text { terdapat dua kriteria pengurutan }\end{array}$ & $80 \%$ \\
\hline 3 & $\begin{array}{l}\text { Penyelesain kasus dengan } \\
\text { menggunakan sort data jika } \\
\text { terdapat tiga kriteria pengurutan }\end{array}$ & $80 \%$ \\
\hline 4 & $\begin{array}{l}\text { Penyelesain kasus dengan } \\
\text { menggunakan filter data jika } \\
\text { terdapat satu kriteria penyeleksian } \\
\text { data }\end{array}$ & $100 \%$ \\
\hline 5 & $\begin{array}{l}\text { Penyelesain kasus dengan } \\
\text { menggunakan filter data jika } \\
\text { terdapat dua kriteria penyeleksian } \\
\text { data }\end{array}$ & $75 \%$ \\
\hline 6 & $\begin{array}{l}\text { Penyelesain kasus dengan } \\
\text { menggunakan filter data jika } \\
\text { menggunakan logika OR atau } \\
\text { logika AND }\end{array}$ & $50 \%$ \\
\hline 7 & $\begin{array}{l}\text { Penyelesaian kasus untuk } \\
\text { mengubah suatu data pada } \\
\text { database Ms Excel yang telah } \\
\text { dimiliki dengan pemanfaatan fitur } \\
\text { di Ms Excel }\end{array}$ & $85 \%$ \\
\hline 8 & $\begin{array}{l}\text { Penyelesaian kasus jika terdapat } \\
\text { data double pada database Ms } \\
\text { Excel yang telah dimiliki }\end{array}$ & $40 \%$ \\
\hline 9 & $\begin{array}{l}\text { Penyelesaian kasus untuk } \\
\text { menjumlahkan atau operasi } \\
\text { numerik lainnya pada data numerik } \\
\text { dari data yang dibutuhkan dengan } \\
\text { dua atau lebih kriteria dasar yang } \\
\text { diberikan }\end{array}$ & $40 \%$ \\
\hline 10 & $\begin{array}{l}\text { Penyelesaian kasus untuk membuat } \\
\text { penyajian data dengan beberapa }\end{array}$ & $60 \%$ \\
\hline
\end{tabular}

\begin{tabular}{|l|l|l|}
\hline No & \multicolumn{1}{|c|}{ Garis Besar Pertanyaan } & $\begin{array}{l}\text { Prosentase } \\
\text { Kebenaran }\end{array}$ \\
\hline & $\begin{array}{l}\text { tampilan yang berbeda dari sumber } \\
\text { data yang sama dengan } \\
\text { menggunakan fitur di Ms Excel }\end{array}$ & \\
\hline
\end{tabular}

Dari tabel tersebut, bisa didapatkan bahwa rata-rata peningkatan pengetahuan yang didapatkan oleh perangkat desa yaitu sebesar $40 \%$. Peningkatan terbesar yang didapatkan ada pada point untuk pengubahan data dengan menggunakan fitur di Ms Excel. Fitur yang dimaksud pada point ini adalah penggunaan fitur form.

\section{ULASAN KARYA}

Pelaksanaan kegiatan Program Pengabdian kepada Masyarakat oleh Tim Dosen Statistika Universitas PGRI Adi Buana Surabaya berjalan dengan lancar. Para peserta palatihan dari Desa Gedangan sangat antusias mengikuti setiap kegiatan yang sudah terjadwal. Kedatangan peserta tepat waktu yaitu sepuluh menit sebelum kegiatan dimulai. Kegiatan dilaksanakan dengan tertib dan lancar.

Kendala yang dihadapi saat pelaksanaan Program Pengabdian kepada Masyarakat oleh Tim Dosen Statistika Universitas PGRI Adi Buana Surabaya adalah lokasi yang digunakan pada kegiatan pelatihan terbuka, sehingga materi yang di tayangkan melalui proyektor tidak begitu terlihat dan lalu lalang orang yang berada di Balai Desa Gedangan dapat terlihat oleh peserta pelatihan sehingga kosentrasi peserta pelatihan terganggu.

Peserta pelatihan sangat antusias dalam mengikuti kegiatan. Hal ini terlihat dari jumlah pertanyaan yang disampaikan yang berhubungan dengan permasalahan 
yang dihadapi oleh peserta yang sesuai dengan materi pelatihan. Para peserta pelatihan berharap jika nantinya kegiatan ini selalu berkesinambungan. Hal ini disebabkan karena kegiatan yang dilakukan oleh Tim Dosen Prodi Statistika UNIPA Surabaya adalah salah satu kegiatan yang sangat menunjang dalam perbaikan keadministrasian sehingga lebih memudahkan peserta pelatihan dalam mengolah data yang dimiliki.

\section{DAMPAK DAN MANFAAT KEGIATAN}

Sesuai dengan penjabaran pada ulasan karya, para peserta pelatihan mengharapkan adanya pelatihan yang berkesinambungan. Salah satu manfaat utama yang didapatkan oleh perangkat desa adalah lebih mudahnya perangkat desa dalam menentukan data pemilih baru yang memenuhi syarat dan menghapus data pemilih lama yang tidak memenuhi syarat. Hal tersebut sesuai dengan hasil peningkatan pengetahuan perangkat desa pada point penggunaan filter data dan pivot table.

Dengan adanya manfaat yang didapatkan tersebut, maka Tim Dosen Prodi Statistika UNIPA Surabaya akan melakukan pembicaraan lebih lanjut dengan perwakilan kepala daerah Kecamatan Sidayu untuk dapat melakukan kegiatan pelatihan yang berkesinambungan dalam peningkatan pengolahan data kependudukan yang ada disetiap desa di Kecamatan Sidayu.

\section{KESIMPULAN}

Pelaksanaan pelatihan manajemen data di Desa Gedangan Kecamatan
Sidayu Gresik yang dilakukan oleh Tim Dosen Prodi Statistika UNIPA Surabaya merupakan suatu upaya untuk meningkatkan pengetahuan perangkat desa dalam memanajemen data. Dengan adanya pelatihan ini, perangkat desa mampu untuk lebih mudah dalam menentukan daftar pemilih yang memenuhi persyaratan. Hal ini sesuai dengan peningkatan kemampuan rata-rata sebesar $40 \%$ yang didapatkan oleh perangkat desa dalam pemanfaatan sort, filter, form, dan pivot table dalam pengolahan data desa.

Dari hasil tersebut, maka salah satu upaya untuk tetap bisa meningkatkan kemampuan dari perangkat desa adalah dengan dilaksanakannya pelatihan yang berkelanjutan mengenai pengolahan data yang dimiliki oleh pihak desa. Bentuk pelatihan tersebut dapat mengenai bagaimana menvisualisasikan data desa agar lebih mudah untuk dibaca/dipahami atau mengenai permasalahan yang lain yang dapat meningkatkan pemahaman perangkat desa guna bisa mengambil keputusan yang tepat dalam membuat suatu kebijakan bagi desa.

\section{DAFTAR PUSTAKA}

[1] Aziz, Noor M. Laporan Akhir Pengkajian Hukum Tentang Pemilihan Kepala Daerah. Badan Pembinaan Hukum Nasional, Kementrian Hukum dan HAM RI. Jakarta : BPHN, 2009.

[2] Pelatihan Pemanfaatan Perangkat Lunak (Microsoft Office Word, Excel, Power Point) Dalam Kinerja Pengolahan Data Di Pemerintahan 
Desa Bagikepala Desa SeKecamatan Batang Angkola. Sormin, Masdelima Azizah, Sahara, Nur and Agustina, Lisna. 2, 2018, MARTABE : Jurnal Pengabdian Masyarakat, Vol. 1, pp. 78-82.

[3] Sosialisasi Pengoperasian Microsoft Excel untuk Administrasi Data Matematis pada Karang Taruna. Julaeha, Siti and Somawati. 03, 2019, Jurnal PKM: Pengabdian kepada Masyarakat, Vol. 02, pp. 280-286.

[4] Pelatihan Microsoft Excel Dan Power Point Bagi Perangkat Desa Sebagai Upaya Peningkatan Administrasi Desa Yang Berkualitas Di Kecamatan Jumantono Kabupaten Karanganyar. Wibowo, Edy. 1, 2017, Adi Widya: Jurnal Pengabdian Masyarakat, Vol. 1, pp. 99-107.

[5] Pengembangan Kemampuan Sumber Daya Manusia melalui Pelatihan Komputer Microsoft Office Excel untuk Meningkatkan Kinerja Perangkat Desa Mranggen. Niati, Asih, Soelistiyono, Anitiyo and Ariefiantoro, Teguh. 1, 2019, EDimas (Educations-Pengabdian kepada Masyarakat), Vol. 10, pp. 105-110.

[6] Pelatihan Pengolahan Data Administrasi Perkantoran Menggunakan Aplikasi Microsoft Excel Pada Balai Desa Pinanggripan Kecamatan Air Batu Kabupaten Asahan. Rizaldi. 2, 2019, Jurdimas (Jurnal Pengabdian Kepada
Masyarakat) Royal, Vol. 2, pp. 107114.

[7] Pelatihan Microsoft Office Untuk Karyawan Dan Kelompok PKK Kelurahan Sawah Baru Tangerang Selatan. Pratiwi, Heny I. Tangerang : PKN STAN Press, 2018. SEMBADHA. pp. 8-13.

[8] Jelen, B. and Alexander, M. Pivot Table Data Crunching: Microsoft Excel 2010. 3nd. Indianapolis, Indiana, USA : Que Publishing, 2011.

[9] Towards an understanding of excel functional skills needed for a career in public accounting : Perceptions from public accountants and accounting students. Ragland, L. and Ramachandran, U. s.l. : Elsevier Ltd, 2014, Journal of Accounting Education, Vol. 32.

[10]Kapasitas Perangkat Desa dalam Penyelenggaraan Pemerintahan Desa di Kabupaten Kudus. Asrori. 2014, Jurnal Bina Praja, pp. 101-116. 